\title{
"Reports of My Death Have Been Greatly Exaggerated": The Continuing Role and Relevance of Election Petitions in Challenging Election Results in the UK
}

\author{
Caroline Morris and Stuart Wilks-Heeg
}

\begin{abstract}
An election petition is the only mechanism through which a UK election result can be challenged. In its current form, the election petition dates back to the Victorian period, when electoral outcomes were routinely challenged on the grounds of corruption. During the twentieth century, the petition mechanism was widely assumed to have become redundant, and no records were kept of its use to challenge election results. However, there has been a renewed interest in election petitions over the past decade and a half, triggered by cases of large-scale electoral fraud and instances of significant failings in the running of elections. Growing calls have been made for the reform of the petition mechanism, but these have typically been unable to draw on anything more than the details of a few dozen petitions that have been tried. Using a new dataset of 302 election petitions from 1900 to 2016, and detailed study of 167 petition cases from 1977 to 2016, this article seeks to fill this gap. In doing so it lends clear weight to the case for reform, with a particular emphasis on the need for a more effective mechanism to investigate and, where appropriate, correct results affected by administrative problems such as vote counting errors.
\end{abstract}

Keywords: election petitions, electoral law, electoral administration, Electoral Commission

\section{INTRODUCTION}

$\mathbf{U}$ NDER UK ELECTORAL LAW, election petitions constitute the only means through which an officially declared election result can be challenged. Despite their legal status, however, election petitions have overwhelmingly been studied by historians rather than legal scholars or political scientists.

Dr. Caroline Morris is a Senior Lecturer in the Department of Law at Queen Mary University of London in London, United Kingdom. Dr. Stuart Wilks-Heeg is a Reader in the Department of Politics at the University of Liverpool in Liverpool, United Kingdom. This research was partly funded by a grant of $£ 2,000$ from the Research Activities Fund of the Society of Legal Scholars.

(C) Caroline Morris and Stuart Wilks-Heeg, 2018; Published by Mary Ann Liebert, Inc. This Open Access article is distributed under the terms of the Creative Commons License (http:// creativecommons.org/licenses/by/4.0), which permits unrestricted use, distribution, and reproduction in any medium, provided the original work is properly cited.
Originating in the fourteenth century, large numbers of election petitions were routinely heard by Parliament in the Georgian and Victorian periods, when elections were notoriously corrupt. A series of legal reforms aiming to address these practices was instituted alongside the extension of the franchise from the 1860s onwards, including the redefinition of the election petition as a judicial, rather than parliamentary, mechanism. From the 1880s, the success of these efforts to eradicate electoral malpractice was evident in a sharp fall in the number of results challenged by petitions. By the early 1900s, parliamentary election results were very rarely subject to petitions and, amid widely held confidence that electoral corruption had been eradicated, attention to election petitions waned.

One consequence of this confidence that the highest standards of electoral integrity had been realized was that no routine data was collected during the twentieth century about the frequency, content, or 
outcomes of election petitions. The Carr Committee's (1948) report on electoral law reform simply noted that very few election petitions had been presented since the 1920s, without providing any further detail. The legal provisions to challenge election outcomes via petitions remained in place. Indeed, the relevant statutes were left virtually unchanged from the Victorian period. But the petition mechanism was treated as essentially redundant. While historians continued to draw extensively on nineteenth-century petitions in their studies of electoral corruption in that period (O'Leary 1962), legal scholars and political scientists paid almost no attention to contemporary petitions from 1945 onwards.

However, recent years have seen a resurgence of interest in election petitions, particularly at the local government level. As part of a wider growth of scholarship on the integrity of UK elections, petitions have begun to receive some academic attention (Stewart 2006; Lardy 2007; Wilks-Heeg 2008; Morris 2012). Petitions have also become the focus of official inquiries, most notably by the UK's Electoral Commission (2012), while also receiving consideration by the Law Commission's (2016) review of electoral law and the Pickles (2016) report on electoral fraud. The reasons for this renewed interest are easy to identify. By the mid-2000s, it had become evident that the liberalization of postal voting under the Representation of the People Act, 2000, had created new opportunities for large-scale electoral fraud. Infamously, at least in UK election circles, Richard Mawrey's Queen's Counsel (QC) (2005) written judgment upon hearing the Aston and Bordesley Green election petitions referred to "evidence of electoral fraud that would disgrace a banana republic" and lambasted the authorities "for a state not simply of complacency but of denial."

The smaller scale of local elections, and the correspondingly smaller scale of margins of victory, have meant that results are more likely to turn on small administrative errors or tightly focused localized malfeasance when compared to parliamentary elections. Electoral law permits a judge to annul or correct an election result in three circumstances only. One is when corrupt or illegal practices have been found; the second, where the winning candidate was ineligible to stand in law. The third occurs in other cases of a breach of election law, when, in the words of section 23(3) of the Representation of the People Act 1983, the election was not conducted so as to be "substantially in accordance" with the rules governing the relevant election and "the act or omission did not affect the result." Despite the opacity of these requirements, these criteria have had the effect of sifting out challenges based on non-material breaches of law. At the same time, it is important to stress that election petitions are not the only legal means through which threats to electoral integrity can be addressed. Breaches of electoral law can be prosecuted in the criminal courts following police investigations, and convictions in such cases are at least as common as successful election petitions. A number of criminal convictions relating to elections have also been brought under fraud or perjury legislation rather than with direct reference to the Representation of the People Act or other bodies of electoral law (Wilks-Heeg 2008).

The renewed interest in election petitions, and calls for their reform, raise intriguing questions about past petitions. The practice of recording data about election petitions and their outcomes has now resumed, notably via the Electoral Commission's annual reports on electoral fraud allegations. However, the lack of even basic data about the volume and outcome of petitions submitted in previous decades raises the issue of whether British elections have been as free from malpractice and maladministration as has been assumed. Likewise, contemporary debates about reforming the petition mechanism operate in a nearvacuum of evidence about past petitions. This article presents significant new data which enables us to shed fresh light on these issues. Based on the records of election petitions catalogued and held by the National Archives, together with records for more recent petitions available from the Electoral Commission and other sources, we have constructed a comprehensive dataset of 302 petitions submitted from 1900 to 2016. We have also undertaken detailed analysis of 167 of the 168 petitions submitted from 1977 to 2016 based on the documentation held by the archives, available law reports, media coverage, and other sources. Our focus here is UK parliamentary and local elections in England and Wales, but we note that our research questions are of general applicability not just to long-established democracies (Orr and Williams 2001) but also to emerging ones (see Orr 2017; Kwa et al. 2003).

The article is presented in three main sections. The first section summarizes the historical evolution of the election petition as a mechanism for challenging election results, its role in helping to eradicate corrupt practices in nineteenth-century elections, and its legacy as a means of mounting legal challenges to elections. It 
is noted that, until very recently, there was an implicit assumption that the petition mechanism was essen tially redundant. Against this backdrop, the second section presents our research findings with respect to long-term trends in the volume of election petitions and detailed analysis of the content and outcomes of election petitions for a 40-year period from 1977 to 2016. Based on the patterns we identify, the final section provides more detailed analysis of the role of petitions in relation to two key issues: the use of petitions to correct election results affected by administrative errors, and the re-emergence of petitions alleging voting offenses, particularly with respect to postal ballots. In light of this evidence, we ask whether petitions are "fit for purpose" as a mechanism for ensuring the integrity of electoral outcomes. We conclude that, as with other aspects of electoral law and administration, election petitions require a significant degree of "retrofitting" if they are to be adapted to the modern age.

\section{THE DEVELOPMENT AND (APPARENT) DEMISE OF ELECTION PETITIONS}

Like most features of the British political system, election petitions have long historical roots. The first recorded challenge to an election was made in 1318, when Matthew de Cranthorn brought a petition before King Edward II and his Council alleging that the sheriff of Devon had made a false return (Morris 2012, 69). In the two-and-a-half centuries that followed, claims of controverted elections were no more than a trickle, but this turned into a flood in the Elizabethan era when the number of boroughs entitled to return a member of Parliament (MP) increased simultaneously with a rise in the prestige attached to being a member (Morris 2012). By this stage, the courts and Parliament held a concurrent jurisdiction over controverted elections. Under the umbrella of the privilege of being able to determine its own composition, Parliament secured sole jurisdiction to decide the outcome of challenged election contests by parliamentary committee in 1702 (Prideaux v. Morrice). Although this approach was frequently criticized for its lack of independence, the state of affairs lasted until the legislative reforms of the 1860s-1880s.

From the Elizabethan through to the Victorian period, corruption, vote-buying, and intimidation were commonplace features of elections (Morris 2012). The volume of petitions alleging corruption peaked in 1865 , when the mechanism was used to challenge the results in 61 separate constituencies on the basis of bribery or other corrupt practices (O'Leary 1962, 234). The Parliamentary Elections Act 1868 (amended slightly in 1879 and 1883) ${ }^{1}$ shifted control over election challenges from the legislature to the judiciary and established the election petition before a two-judge election court as the primary vehicle for doing so. Parliament's ability to determine election outcomes was thereby extinguished ( $\S \S 11-13)$, although Parliament still retains the power to discipline and expel its members once elected. This reform occurred alongside other Victorian efforts to address corruption in elections. The Corrupt Practices Act of 1854 outlawed practices such as bribery, treating (providing food, drink, or entertainment in an attempt to influence how someone votes), and intimidation. The Ballot Act of 1872 introduced the secret ballot. The Corrupt and Illegal Practices Act of 1883 consolidated the 1854 Act while also placing limits on the election expenditure of candidates.

These Acts, as consolidated by the Representation of the People Acts of 1949 and 1983, have remained the central planks of British electoral law ever since (Butler 1999; Watt 2006). Butler's (1999, 173) observation that, since the Victorian age, "electoral law has stood almost still," applies particularly well to the provisions for election petitions. Despite enormous changes over the past 150 years in how elections are conducted, the process for challenging an election result remains largely unchanged (Grist 2015). Attempts to reform or modernize the petitions process have been thin on the ground. The Carr Committee's (1948) report on electoral law proposed several reforms to the petition process, but none eventuated. More recent reform recommendations (Law Commission 2016; Pickles 2016) have yet to be put before Parliament. The expansion of the franchise and a proliferation of elected bodies and of the electoral systems used to return them have all taken place without any fundamental change to the petitioning process. Instead, the existing system of petitions has been extended to these new electoral contexts, with only modest adaptations, via a range of primary and secondary legislation essentially "bolted on" to the 1868 legislation.

\footnotetext{
${ }^{1}$ The Parliamentary Elections Act 1868 was enacted as the Election Petitions and Corrupt Practices Act. The amending legislation was contained in the Parliamentary Elections and Corrupt Practices Act 1879 and the Corrupt and Illegal Practices Act 1883.
} 


\section{The nature of the petition process}

Following Grist (2015), we can identify four core features of election petitions defined by the 1868 Act and which remain in place. First, election petitions are private legal actions. A petition may be brought by a candidate at the election or by an elector (in the case of a local election petition, four electors are needed). Petitions cannot be initiated by political parties as they can in other jurisdictions. If a political party wishes to challenge an election result, it must bring the petition in the name of an individual member. Likewise, returning officers, other electoral officials, and public bodies have no standing to lodge a petition. This highly individualized approach to petitions stems from the era in which the legislation was framed, when political parties were far less significant as organized actors in the electoral field.

Second, petitioners are required to adhere to strict procedural requirements. A petition must be submitted on a prescribed form and provide prescribed information to the Election Petitions Office at the Royal Courts of Justice in London within 21 days of the date of the return or the election. A further seven days are allowed in cases of allegations of corrupt or illegal practices relating to the payment of money or in cases relating to election expenses. No extension to these time limits is possible (Ahmed v. Kennedy [2002]). Once submitted, the petition grounds cannot be amended. A separate application to fix security for costs must also be made. Notice that the petition has been lodged, the nature and amount of security given by the petitioner, and the petition itself must be served on the respondent within five days. The petitioner also has to apply to a rota judge for a time and place to be fixed for the hearing of the petition. A petition can be struck out if these formalities are not complied with (Absalom v. Gillett [1995]; Ahmed v. Kennedy [2002]; but see Miller v. Bull [2009] casting doubt on this strict approach). Once the petition has been lodged, it can only be withdrawn with leave of the court. Furthermore, there is no ability for one petitioner to withdraw and be replaced by another on the same petition (as the petition lodged in 2011 with respect to the Appleby Ward of North West Leicestershire District Council demonstrated).

Third, petitions involve substantial financial outlay. A fee of $£ 465$ is payable up-front to issue a petition, with a further fee of $£ 45$ to apply to fix the amount of security for costs. Security for costs is then typically $£ 2,500$ for a local election and $£ 5,000$ for a parliamentary election. Legal aid is generally not available in petition cases (Hussein v. Khan). An unsuccessful petitioner may also be liable to pay the costs of the other side, which can be substantial.

Fourth, petitions are determined by a specially convened election court, and the opportunities for appeal are limited. An election court comprises two judges (for a parliamentary election) or an election commissioner (for a local election) without a jury. An election court judge or election commissioner may conduct the hearing in an inquisitorial manner (this being a relic of the approach of parliamentary committees which used to hear petitions), but the burden of proof remains with the petitioner. If the election court accepts the grounds on which the petition is presented, it will result in a decision that the declared winner was not duly elected. In instances where this involved corrupt or illegal practices, or where the winning candidate was ineligible, the election will be voided, thus triggering a fresh contest. An election court is also empowered, where relevant, to correct the result via a process known as "scrutiny." In cases where an error has occurred in the counting, recording, or inclusion/exclusion of votes, it is therefore possible for the court to declare the election undue and name another candidate as the winner. In the interests of finality, the legislation provides no scope to appeal election court decisions although, following $R$ (on the application of Woolas) v. Parliamentary Election Court (2010), it has now been established that a petition judgment for a parliamentary election can be judicially reviewed. Appeals are therefore restricted to considerations of whether the law governing petitions has been followed and are not permitted to challenge any other issues of fact (Grist 2015).

\section{The legal grounds for election petitions}

While the above discussion implies that election petitions can only be brought with reference to very particular grounds, there is no express legal definition of those grounds. The Law Commission has commented that the relevant grounds of challenge must be "divined from different sections" of the Representation of the People Act 1983. Moreover, as the Electoral Commission (2012) observes, the legal framework for petitions is found additionally in up to 13 other pieces of primary and secondary 
legislation as well as mostly unreported case law. Some of the grounds set out in the Representation of the People Act 1983 are not particularly clear, referring only to an "undue election or undue return" (Representation of the People Act 1983, $\S \S 120(1)$, 127(b), 164-165). Since the meaning of these terms is left undefined in the statute, they can only be found in case law. Moreover, some of the rules relating to the determination of election must be discovered by reference to the "principles, practices and rules on which committees of the House of Commons used to act in dealing with election petitions" (Representation of the People Act 1983, $\S 157(2)$ ).

Despite this formal legal complexity, it has become clear, in practice, that there are three sets of grounds on which an election outcome can be challenged. First, an election petition may legitimately make allegations of electoral offenses-specified as corrupt or illegal practices in the Representation of the People Act 1983 or elsewhere-that were committed during the campaign. So-termed "corrupt" practices directly reflect the concerns of the Victorian legislators to eradicate attempts to pressurize or intimidate voters, or to buy or steal their votes. The relevant offenses are defined as bribery, treating, undue influence (including undue spiritual influence), and personation. The Electoral Administration Act 2006 created new offenses relating to postal and proxy voting. By contrast, "illegal" practices include such activities as: failing to include stipulated information on leaflets, in newspaper advertisements, or on posters about the printer, promoter, and person on whose behalf the information is being published ("an imprint offense"); disturbing a lawful public meeting in a locality when an election is imminent; and making a false statement about the personal character or conduct of a candidate, including that a candidate has withdrawn from the election.

Corrupt and illegal practices have a particular salience because of their consequences for respondents who are found guilty. A petition that is upheld on grounds of corrupt or illegal practice will void the election, remove the winning candidate from office, and disqualify all those found guilty from standing for election for three (in the case of an illegal practice) or five years (for a corrupt practice). In two particular cases of corrupt practices, personation and certain proxy and postal voting offenses, and the illegal practices relating to voting misconduct, including voting when ineligible to vote and voting more than once, the offender will also be disenfranchised for a period (Representation of the People Act 1983, $\S \S 61$ and 62A).

Second, a petition may question the eligibility of the successful candidate to stand for election. While candidate restrictions are clearly set out in legislation, a returning officer has no ability to refuse the nomination of a potential election candidate (other than convicted prisoners) on the grounds that he or she considers that the candidate is disqualified from standing. Challenges can only be made after the election, via an election petition.

Third, a petition may legitimately base its claims on administrative irregularities that took place in the nomination process, the organization of the poll, or the counting of votes. This category covers an almost unlimited range of conduct, and its focus is not so much on deliberate infringements of electoral integrity but on genuine mistakes and errors made by election officials. The majority of such cases relate to counting or transposition errors, or allegations about the wrongful inclusion or exclusion of ballot papers. Petitions which fail to base their claims on one or more of these three grounds have consistently failed, even where they made a strong prima facie case that electoral irregularities had occurred. Moreover, a breach of election law is not in itself sufficient to void or amend an election result. The court or commissioner must also be persuaded that the election was not conducted so as to be substantially in accordance with the law as to elections, and the act or omission directly affected its result.

\section{The (assumed) demise of the election petition}

One reason for the lack of reform of the petitioning process was the commonly held view for much of the twentieth century that election petitions were largely redundant. With the progressive elimination of corrupt practices, the incidence of parliamentary election petitions also diminished. By the early 1900s, petitions submitted after general elections were typically in single figures, and no parliamentary election result was successfully challenged on grounds of corrupt practices or illegal practices at the general elections or parliamentary by-elections held from 1929 to 2005 (Stewart 2006, 657). Small numbers of petitions did continue to challenge parliamentary election results on grounds other than corrupt and illegal practices, but only four constituency results were overturned from 1929 to 2005 (Rallings and Thrasher 2006). A further successful petition relating to a parliamentary 
election was heard after the 2010 general election (Electoral Commission 2012). These five successful petitions resulted in three parliamentary elections being declared undue and two declared void.

All three verdicts of undue elections arose from 1955 to 1961 and involved petitions being used to establish the legal ineligibility of the winning candidate to stand for election to the House of Commons, resulting in the second-placed candidate being returned (O'Leary 1965). All three cases were unusual. In 1955, two Sinn Fein candidates were elected in Northern Ireland: Philip Clarke in Fermanagh and South Tyrone and Thomas Mitchell in MidUlster. Sinn Fein's participation in the 1955 general election was an act of protest, and neither Clarke nor Mitchell intended to take their seats at the Westminster Parliament. Both were also serving jail sentences for their involvement on a raid on a military barracks and were therefore disqualified on grounds of being felons. The third, and better-known, case dates from 1961 and resulted in Tony Benn's disqualification following his victory in the 1961 Bristol South East by-election, with the Conservative candidate, Malcolm St Clair, being returned to the Commons in his place. The by-election had been called on the grounds that Benn had inherited his father's peerage and, as a member of the House of Lords, could no longer remain in the Commons. Benn sought to renounce the peerage and remain an MP by standing, and winning, the 1961 byelection. Following his disqualification, Benn continued to campaign on the issue, resulting in the Peerage Act of 1963, which allowed inherited peerages to be renounced. Benn returned to the Commons in August 1963 following a subsequent by-election, triggered by St Clair resigning the seat.

The only two parliamentary elections to be voided by election courts after 1924, and to involve election results being successfully contested on grounds of malpractice or maladministration, were those in Winchester in 1997 and Oldham East and Saddleworth in 2010. In the former case, the Liberal Democrat candidate, Mark Oaten, had been declared the winner by two votes following a series of recounts. A petition was issued by defeated Conservative candidate, Gerry Malone, on the grounds that 54 ballot papers had been excluded from the count owing to the failure of the polling station staff to stamp them and their subsequent exclusion by the returning officer. Oaten did not challenge the petition, and the court voided the election. At the subsequent by-election, Oaten secured a greatly increased majority of more than 21,000 votes over Malone. In the Oldham East and Saddleworth case, the petitioner was the narrowly defeated Liberal Democrat candidate, Elwyn Watkins, who alleged that false statements had knowingly been made about his character by the victor, Labour's Phil Woolas. The court found Woolas guilty of an illegal practice, barring him from holding public office for three years, and voided the election, which the respondent had won by 103 votes. At the subsequent by-election, the seat was won by Labour's Debbie Abrahams with an increased majority of 3,600 votes over Watkins.

Given the rarity of petitions, the prevailing wisdom was that they were essentially irrelevant. As Orr $(2015,176)$ notes, some 8,500 constituency elections were held in England from 1931 to 1992, none of which were challenged by any of the three major parties on grounds of malpractice or maladministration. However, there are also strong grounds to doubt the assumption that the absence of petitions denoted an absence of grounds for them. In their account of the 1959 general election, Butler and Rose $(1959,280)$ propose that the lack of petitions "is not because malpractices are never suspected (although serious ones must have been very rare) but because the process of petitioning is expensive and uncertain." The same authors quote a senior party official who suggested that, while there were occasional grounds on which a result could be challenged, doing so "might start tit-for-tat petitions and no party could afford a lot of them" (Butler and Rose 1959, 280). A similar point is made by Orr $(2015,176)$ when he notes that the "litigational quietude was said to reflect a gentleman's agreement between the major British parties." In practice, administrative errors were sometimes made and electoral laws occasionally breached, but "the tacit agreement was to the effect that problems in elections were to be treated as inevitable mistakes rather than conspiracies, mistakes whose partisan effects would even out over time" (Orr 2015, 176).

The prevailing view of the insignificance of election petitions was reinforced by the absence of information about them. The very limited academic attention to petitions before the 2000s centered on the few parliamentary petitions which had been heard by an election court. As we note later in this article, there were several more petitions challenging 
parliamentary election results in this period but which were withdrawn or dismissed before trial. Moreover, until very recently, no data at all were available for second-tier elections, particularly those to local councils and, from 1979 onwards, to the European Parliament. Again, we show in the remainder of this article that the petition mechanism continued to be used, albeit infrequently, to challenge local election results throughout the twentieth, and into the twenty-first century. The evidence provided by these petitions and subsequent hearings and judgments are an invaluable means of assessing the extent to which problems with the conduct of elections had previously remained hidden. Our data also has a direct bearing on current debates about whether election petitions are "fit for purpose."

\section{ELECTION PETITIONS, 1900-2016: A NEW DATASET}

Our dataset on election petitions from 1900 to 2016 was constructed in three stages. ${ }^{2}$ The first stage involved compiling a comprehensive database of all UK parliamentary petitions, and all local election and European election petitions in England and Wales, from 1900 to 2007, using the National Archive catalogue of records. These records allowed us to establish the year of the petition, the elected body to which it related, and the name(s) of the petitioner(s) and the respondent(s). Using this information, we were able to code each petition using the current geography of UK counties and regions/countries. We also sought to cross-check our data against other official information, primarily parliamentary written answers. In the second stage, we undertook a detailed analysis of all available records in the National Archives of petitions from 1977 to 2007, enabling us to code and record key details of each case, notably the grounds and the outcome of the petition, including the reasons for petitions failing to proceed or being dismissed at trial. In the third and final stage, details of election petitions from 2008 to 2016 were obtained from UK Electoral Commission reports, media coverage, parliamentary written answers, published legal judgments, and law reports.

The information we accessed on petitions from 1977 to 2016 enabled us to identify the grounds for these petitions and their success rates. Petitions in this period were classified by their stated grounds using the twofold categorization of the Electoral
Commission. Thus, petitions were coded as to whether they primarily relate to an error on the part of an election official (administrative errors) or allege that an election candidate, or the candidate's agent, committed a statutory election offense (wrongdoing by candidates/agents). While the Election Commission has noted that these categories can overlap, we were able to assign a primary set of grounds to each case. We then coded a number of sub-categories for analysis. Administrative errors were subdivided into four groups: ballot papers incorrectly included or excluded in the count; counting/computational errors; procedural defects in the election; and the returning officer failing in their duties. With respect to wrongdoing by candidates or agents, we added two further levels of categorization. An initial distinction was made between campaign offenses, candidate offenses, and voting offenses. Each of these sub-categories was then further broken down. Campaign offenses were classified as either false statements, false declaration of expenses, or broadcasting offenses. Candidate offenses comprised either ineligibility/disqualification from standing or nomination offenses. Finally, voting offenses were sub-coded as bribery/treating, personation, postal vote fraud, registration fraud, or undue influence. In a number of cases, particularly those involving voting offenses, additional categories of offense were added. In a very small number of cases, grounds were classified as "spurious" or there was not enough information to classify them.

\section{Frequency, type, and geography of election petitions, 1900-2016}

For the period 1900-2016, we identified a total of 302 petitions. Cross-checking was carried out against the only other source of information about the incidence of election petitions: ministerial responses in Hansard to written questions from MPs (House of Commons [HC] Debate [Deb] 30 July 1982; HC Deb 22 November 1995; HC Deb 24 May 2005; HC Deb 22 March 2007; HD Deb 28 March 2007; HC Deb 25 February 2013). While the information provided in parliamentary records is fragmented, these cross-checks enable us to be confident about the comprehensiveness of our data. For local elections,

\footnotetext{
${ }^{2}$ We record here our thanks to Dr. Patrick Graham of the University of New England, who acted as research assistant to this stage of the project.
} 
60

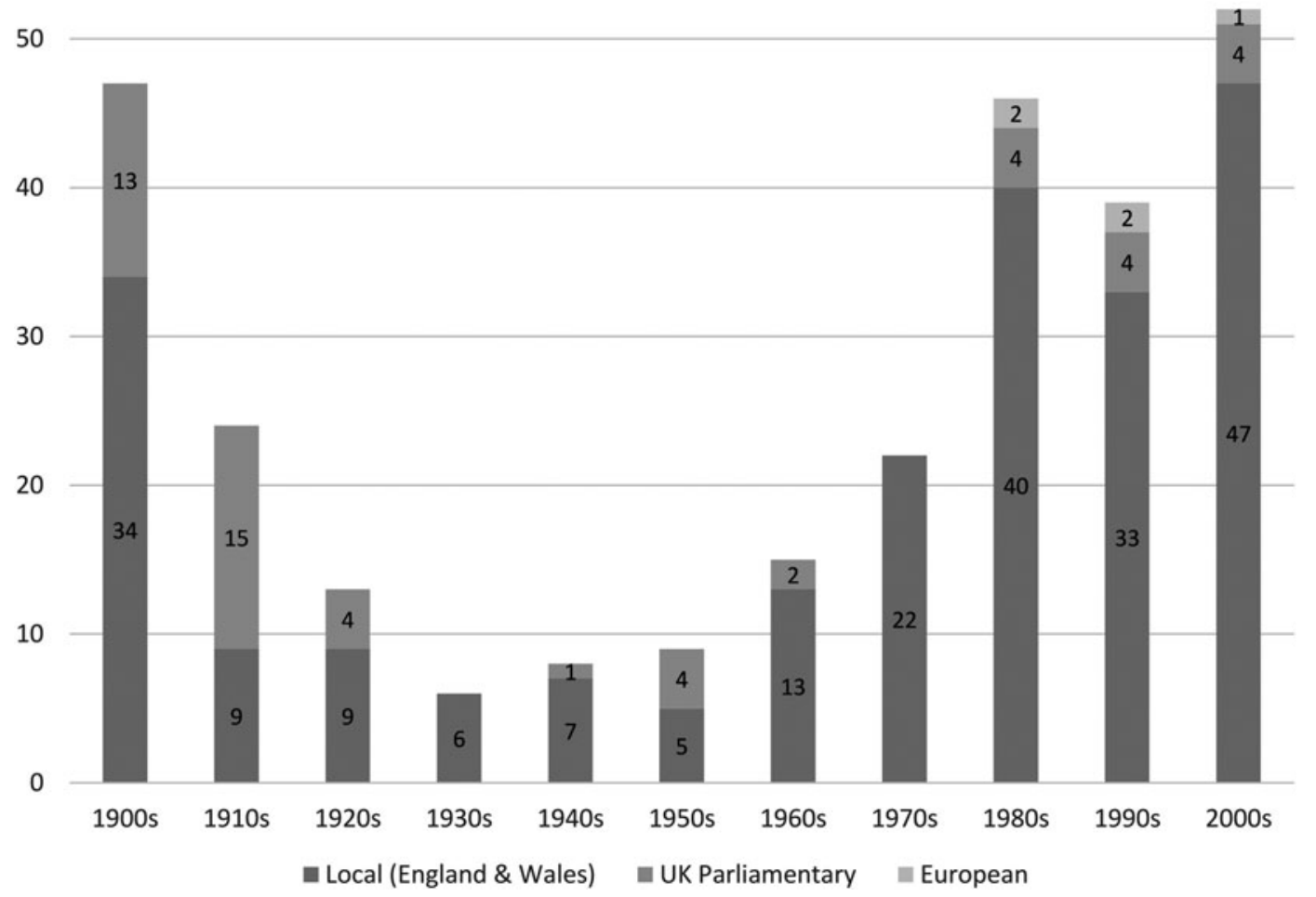

FIG. 1. Election petitions lodged, by decade and election type, 1900-2009.

our figures match those provided for all 29 years in which written answers provided annual breakdowns (1962-1982 and 1997-2006). Where modest discrepancies are apparent, there are good reasons to assume that these either reflect errors in the parliamentary answers concerned or stem from a lack of clarity in Hansard about the UK jurisdictions to which the figures apply.

Evidently, if 302 petitions have been lodged since 1900 , only a tiny proportion of election outcomes have been challenged. Nonetheless, it is also clear that petitions did not cease or become redundant after the 1920s. Legal challenges to election outcomes continued to occur, predominately in local elections. Figure 1 shows the number of petitions lodged, by decade and by type of election, from 1900 to 2009.

Three points of note are revealed by the data. First, the overall trend in the volume of petitions since 1900 is striking. While the total number of petitions fell sharply over the first four decades of the twentieth century, from the 1960s onwards there is a very clear upward trend. Indeed, the rise in the number of petitions from the 1960s to the 1980s almost perfectly mirrors the decline from the 1900s to the 1920s. Moreover, the number of petitions submitted in recent decades has consistently been at a far higher level than in the middle part of the twentieth century. The 51 petitions lodged in the 10 years from 2000 to 2009 not only represented the highest during any single decade since 1900 but also exceeded the total submitted during the 40 years from 1930 to 1969. Second, this rise in the overall number of petitions from the 1960s onwards is overwhelmingly accounted for by the increase in the number of local election petitions. Just five petitions relating to local elections were lodged in the 1950s, but there were 47 in the first decade of the twentyfirst century. While parliamentary election petitions have become more frequent in recent years, they remain rare, with fewer than five lodged per decade from the 1920s onwards. Third, although the numbers are small, it is nonetheless notable that petitions relating to parliamentary elections were lodged in every decade other than the 1930s and 1970s. Our dataset indicates a higher number of parliamentary election petitions than appears in the standard 
Table 1. Geographical Origins of Election Petitions, 1900-2016, by Current UK Standard Regions

\begin{tabular}{|c|c|c|c|c|c|c|c|c|}
\hline & \multicolumn{2}{|c|}{$1900-1939$} & \multicolumn{2}{|c|}{$1945-1980$} & \multicolumn{2}{|c|}{$1981-2016$} & \multicolumn{2}{|c|}{ Total, 1900-2016 } \\
\hline & No. & $\%$ & No. & $\%$ & No. & $\%$ & No. & $\%$ \\
\hline North West & 6 & 6.7 & 5 & 9.3 & 14 & 8.9 & 25 & 8.3 \\
\hline North East & 4 & 4.4 & 1 & 1.9 & 7 & 4.4 & 12 & 4.0 \\
\hline West Midlands & 7 & 7.8 & 3 & 5.6 & 22 & 13.9 & 32 & 10.6 \\
\hline East Midlands & 4 & 4.4 & 3 & 5.6 & 8 & 5.1 & 15 & 5.0 \\
\hline Yorkshire and the Humber & 9 & 10.0 & 4 & 7.4 & 10 & 6.3 & 23 & 7.6 \\
\hline South East & 8 & 8.9 & 4 & 7.4 & 19 & 12.0 & 31 & 10.3 \\
\hline Eastern & 11 & 12.2 & 9 & 16.7 & 15 & 9.5 & 35 & 11.6 \\
\hline South West & 23 & 25.6 & 5 & 9.3 & 14 & 8.9 & 42 & 13.9 \\
\hline Greater London & 9 & 10.0 & 9 & 16.7 & 34 & 21.5 & 52 & 17.2 \\
\hline Wales & 9 & 10.0 & 8 & 14.8 & 11 & 7.0 & 28 & 9.3 \\
\hline Scotland & 0 & 0.0 & 1 & 1.9 & 1 & 0.6 & 2 & 0.7 \\
\hline Northern Ireland & 0 & 0.0 & 2 & 3.7 & 3 & 1.9 & 5 & 1.7 \\
\hline TOTAL & 90 & 100 & 54 & 100 & 158 & 100 & 302 & 100 \\
\hline
\end{tabular}

reference sources, notably Rallings and Thrasher (2009). ${ }^{3}$

There has also been a clear shift over time in the localities from which election petitions originate. Table 1 shows the number of petitions by current UK standard region across three time periods of roughly equal lengths. From 1900 to 1939, the region that accounted for the highest proportion of petitions, 26 percent, was South West England, yet the South West's share had fallen to just nine percent by 1981-2016. Two other English regions also show a clear, although less dramatic, fall over time-Eastern England, and Yorkshire and the Humber-as does Wales. Meanwhile, Greater London shows the opposite trend. The capital accounted for 10 percent of petitions from 1900 to 1939 , but this had risen to 21 percent by 1981-2016. The other English regions with notable increases in the number and share of petitions are the West Midlands and, to a lesser extent, the South East. Further analysis, based on current English counties, demonstrates a clear rural to metropolitan shift over time. In the early decades of the twentieth century, petitions were more likely to originate from rural than metropolitan areas. From 1900 to 1939,10 percent of petitions were lodged with respect to elections in London and a further 12 percent related to elections in the territories now covered by England's six metropolitan counties. Conversely, the predominately rural counties of Gloucestershire, Devon, Lincolnshire, Dorset, and Cumbria collectively accounted for 31 percent of petitions. By the end of the century, this pattern reversed. From 1981 to 2016, 40 percent of petitions related to elections in the major conurbations (London plus the six metropolitan coun- ties), while only seven percent were accounted for by the five mainly rural counties listed above.

Subdividing the period from 1981 to 2016, when a total of 158 petitions were lodged, clarifies that the shift to metropolitan areas is particularly evident from the late 1990s onwards. During the 17 years from 1981 to 1998,24 out of 77 petitions (31\%) related to elections in London or the six other major English conurbations. However, over the next 17year period, from 1999 to 2016,39 out of 81 petitions $(48 \%)$ concerned electoral contests in these metropolitan areas. A particularly high volume of petitions arose from two conurbations: 30 of the $81(37 \%)$ petitions from 1999 to 2016 related to either London or the metropolitan county of the West Midlands (centered on the city of Birmingham). Indeed, 16 petitions in this period, comprising 20 percent of the total, concerned elections in either the city of Birmingham or the London Borough of Tower Hamlets alone. As we discuss later in this article, the geographical concentration of cases in these two local authorities is very much associated

${ }^{3}$ Rallings and Thrasher (2009) do not include the petitions lodged after parliamentary elections in 1948 (Croydon North by-election); 1983 (Penrith; Poole; and Hyndburn; general election); and 1992 (Belfast West, general election). In addition, one of the petitions lodged after the 1997 general election (it is unclear which) is omitted by Rallings and Thrasher. Some of these discrepancies are likely to arise from Rallings and Thrasher following the practice established by Craig (1976, 107) of excluding petitions which did not proceed due to the petitioner's failure to lodge security for costs. However, both the Penrith and Belfast West petitions proceeded to trial. 
Table 2. Primary Grounds for Election Petitions Lodged from 1977 to 2016

\begin{tabular}{lcccc}
\hline & $\begin{array}{c}\text { Total number of } \\
\text { petitions lodged }\end{array}$ & $\begin{array}{c}\text { Petitions alleging } \\
\text { official error (\% of all } \\
\text { petitions within period) }\end{array}$ & $\begin{array}{c}\text { Petitions alleging } \\
\text { candidatelagent wrongdoing } \\
\text { (\% of all petitions within period) }\end{array}$ & $\begin{array}{c}\text { Petitions with unknown } \\
\text { or spurious grounds (\% } \\
\text { of all petitions within period) }\end{array}$ \\
\hline $1977-1986$ & 40 & $23(58 \%)$ & $16(40 \%)$ & $1(3 \%)$ \\
$1987-1996$ & 43 & $19(44 \%)$ & $24(56 \%)$ & $0(0 \%)$ \\
$1997-2006$ & 50 & $28(56 \%)$ & $19(38 \%)$ & $3(6 \%)$ \\
$2007-2016$ & 35 & $19(54 \%)$ & $15(43 \%)$ & $1(3 \%)$ \\
TOTALS & 168 & $89(53 \%)$ & $74(44 \%)$ & $5(3 \%)$ \\
\hline
\end{tabular}

Percentages may not sum due to rounding.

with the growth in the number of petitions challenging outcomes on the grounds of voting offenses.

Grounds and outcomes of election petitions, 1977-2007

The additional detail provided by studying the archival records of individual election petitions allows for a much more extensive analysis of their role and significance in challenging election outcomes. In particular, we have been able to ascertain the stated grounds for all but one of the 168 election petitions lodged from 1977 to 2016, as well as the outcome of the petition process in all but two of these cases. In turn, this information enables us to identify whether the most common grounds for challenging election outcomes have changed over time and whether some grounds have been more likely to result in a successful challenge to an election result than others.
Submitted petitions divide almost equally between the two main categories of official errors and partisan wrongdoing. As set out in Table 2, 89 (53\%) of the 168 petitions lodged from 1977 to 2016 cited errors made by election administrators as their primary grounds, while $74(44 \%)$ primarily made allegations of wrongdoings by candidates or their election agents. The remaining five petitions (3\%) comprised four which made highly spurious claims, such that it was impossible to categorize them, and one for which no records were available in the National Archives. The broadly equal balance between the two primary groupings shows little variation over time.

A similar stability is evident with respect to some of the sub-categories of petition grounds, set out in Table 3. For instance, petitions alleging counting or computational errors consistently made up around 20 percent of all election challenges in each of the four time periods. Similarly, the number and

Table 3. Grounds for Election Petitions Lodged from 1977 to 2016, by Sub-Category (Percentage of All Petitions in Period Falling into This Sub-Category)

Petitions Alleging Errors by Election Officials

\begin{tabular}{|c|c|c|c|c|}
\hline & $\begin{array}{c}\text { Ballot papers incorrectly } \\
\text { included or excluded }\end{array}$ & $\begin{array}{c}\text { Counting or } \\
\text { computational errors }\end{array}$ & $\begin{array}{l}\text { Procedural defects } \\
\text { in election/returning } \\
\text { officer failed in duties }\end{array}$ & Total \\
\hline 1977-1986 & $7(18 \%)$ & $7(18 \%)$ & $9(23 \%)$ & $23(58 \%)$ \\
\hline 1987-1996 & $4(9 \%)$ & $9(21 \%)$ & $6(14 \%)$ & $19(44 \%)$ \\
\hline 1997-2006 & $6(12 \%)$ & $11(22 \%)$ & $11(22 \%)$ & $28(56 \%$ \\
\hline 2007-2016 & $1(3 \%)$ & $7(20 \%)$ & $11(31 \%)$ & $19(54 \%)$ \\
\hline TOTAL & $18(11 \%)$ & $34(20 \%)$ & $28(17 \%)$ & $89(53 \%)$ \\
\hline \multicolumn{5}{|c|}{ Petitions Alleging Wrongdoing by Candidates or Agents } \\
\hline & Campaign offenses & Candidate offenses & Voting offenses & Total \\
\hline 1977-1986 & $11(28 \%)$ & $4(10 \%)$ & $1(3 \%)$ & $16(40 \%)$ \\
\hline $1987-1996$ & $15(35 \%)$ & $6(14 \%)$ & $3(7 \%)$ & $24(56 \%)$ \\
\hline 1997-2006 & $5(10 \%)$ & $3(6 \%)$ & $11(22 \%)$ & $19(38 \%)$ \\
\hline $2007-2016$ & $6(17 \%)$ & $4(11 \%)$ & $5(14 \%)$ & $15(43 \%)$ \\
\hline TOTAL & $37(22 \%)$ & $17(10 \%)$ & $20(12 \%)$ & $74(44 \%)$ \\
\hline
\end{tabular}


Table 4. Success Rate of Election Petitions Lodged from 1977 to 2016, by Grounds for Submission

\begin{tabular}{lcccc}
\hline & Success rate of & $\begin{array}{c}\text { Success rate of } \\
\text { petitions alleging } \\
\text { official error }(N)\end{array}$ & $\begin{array}{c}\text { Success rate of petitions } \\
\text { alleging candidatelagent } \\
\text { wrongdoing }(N)\end{array}$ & $\begin{array}{c}\text { Success rate of } \\
\text { other petitions }(N)\end{array}$ \\
\hline $1977-1986$ & $30 \%(12)$ & $48 \%(11)$ & $7 \%(1)$ & Unknown \\
$1987-1996$ & $37 \%(16)$ & $68 \%(12)$ & $17 \%(4)$ & N/a \\
$1997-2006$ & $40 \%(20)$ & $60 \%(17)$ & $16 \%(3)$ & $0 \%(0)$ \\
$2007-2016$ & $34 \%(12)$ & $37 \%(7)$ & $33 \%(5)$ & $0 \%(0)$ \\
TOTALS & $36 \%(60)$ & $53 \%(47)$ & $18 \%(13)$ & $0 \%(0)$ \\
\hline
\end{tabular}

Percentages may not sum due to rounding.

proportion of petitions whose grounds are centered on candidate offenses shows limited variation over time. By contrast, petitions alleging campaign offenses show a clear peak from 1987 to 1996, while those citing errors in decisions about the inclusion or exclusion of individual ballot papers from the count declined sharply during 20072016. Of particular note, however, is that petitions lodged with reference to voting offenses increased dramatically from the late 1990 s, making up 22 percent of all petitions from 1997 to 2006 and 14 percent of those lodged from 2007 to 2016 (compared to just 3\% during 1977-1986). In total, voting offenses provided the grounds for 16 petitions from 1997 to 2016, with 11 of these petitions originating from Birmingham or Tower Hamlets. These petitions are the primary reason for these two local authorities accounting for a hugely disproportionate share of petitions in recent decades.

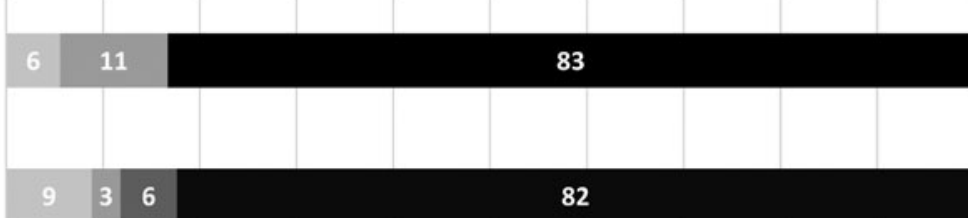

Counting or computational error $(\mathrm{N}=34)$

Candidate offences $(\mathrm{N}=17)$
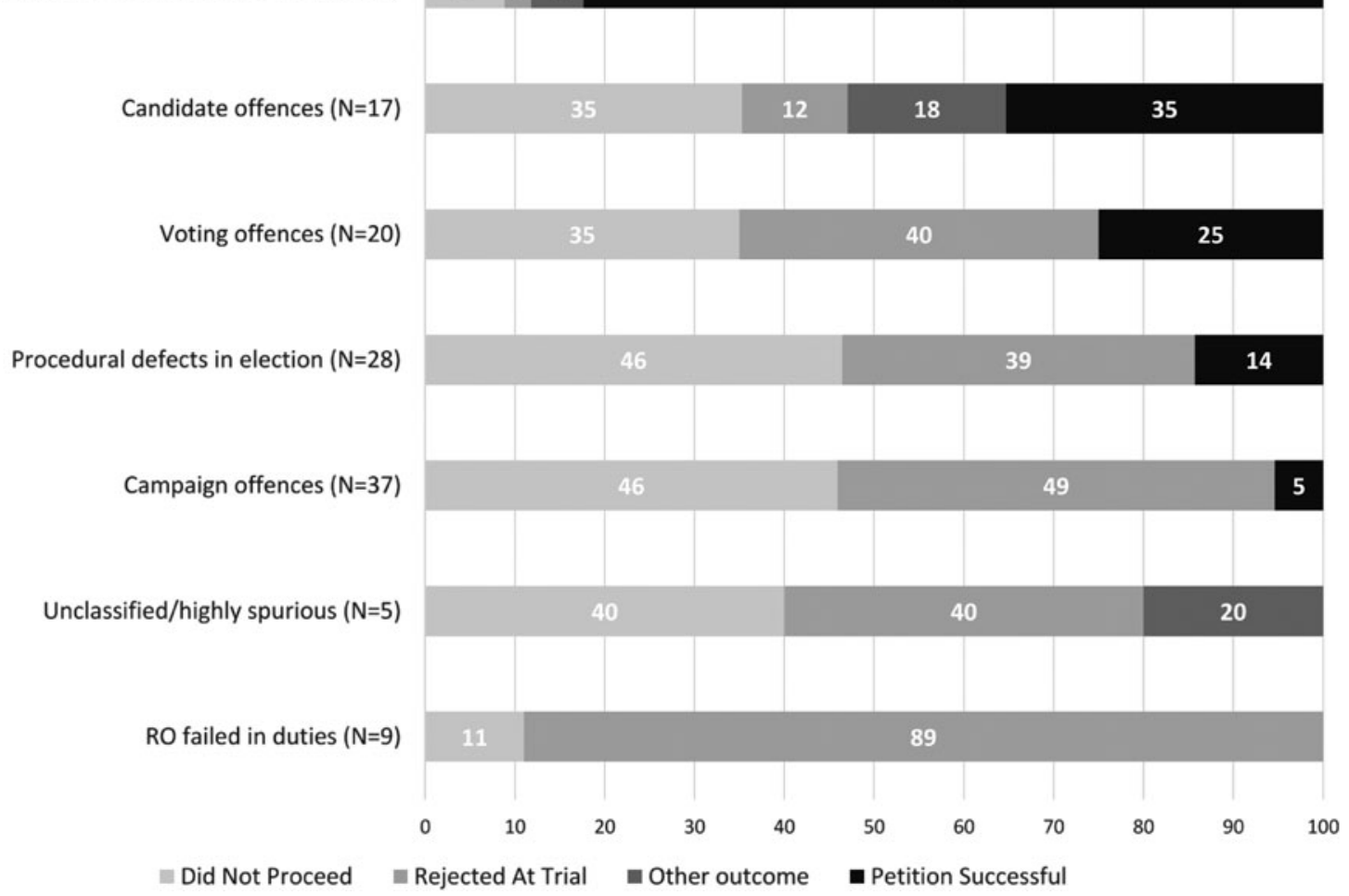

FIG. 2. Outcomes of election petitions lodged from 1977 to 2016, by primary grounds for petition (\%). 
A further point of significance emerges when the grounds of successful petitions only are considered, i.e., those which resulted in an election being declared either void or undue. Table 4 shows that, over the 40-year period studied, 53 percent of petitions alleging official errors were ultimately successful, whereas the success rate was only 18 percent for petitions whose claims were primarily centered on candidates or agents. There was no discernible trend over time in the success of petitions alleging official errors. By contrast, where the grounds centered on the actions of candidates or agents, there is a clear rise over time in the proportion of successful petitions. From 1977 to 1986, just one of the $16(6 \%)$ petitions in this overall category resulted in election results being voided or declared undue. By 2007-2016, the figure had risen to five of 15 petitions lodged (33\%).

Subdividing petitions further by the types of allegations made reveals more about the circumstances under which election results have been successfully challenged. Figure 2 shows the breakdown of petition outcomes from 1977 to 2016 in the seven primary sub-categories of grounds cited, plus the outcomes for petitions which were either unclassified or coded as "highly spurious." As this chart highlights, there are large variations in petition outcomes by sub-category. Where the primary grounds related either to allegations that ballot papers were incorrectly included or excluded from the final count, or to suggestions that a counting or computational error was made in the declared result, over $80 \%$ of petitions were successful. Success rates were considerably lower in all other sub-categories. Indeed, seven in every ten petitions which succeeded from 1977 to 2016 concerned instances where election courts essentially made corrections to a declaration of results made by the returning officer. While the numbers are small, petitions concerned with wrongdoing by candidates or agents were most commonly successful where they alleged candidate offenses, such as ineligibility to stand for office. However, there is also a notable shift from the late 1990s onwards. From 1977 to 1996, four petitions alleging candidate offenses were successful, compared to just one for campaign offenses and none at all for voting offenses. However, from 1997 to 2006, there were five successful petitions alleging voting offenses, compared to two instances where results were overturned on grounds of candidate offenses and one instance due to campaign offenses.

\section{WHAT ARE ELECTION PETITIONS REALLY FOR?}

From the patterns and trends outlined, we identified two key tendencies to explore in more detail via the records of the 168 petitions submitted from 1977 to 2016. Both raise important questions about whether the Victorian petition mechanism remains "fit for purpose" and, if so, what that purpose might be. The first tendency is the predominance of cases involving official mistakes among successful petitions. Despite petitions originating as a mechanism for tackling corrupt practices in parliamentary elections, the most frequent effective use of petitions today is in providing redress for administrative errors in local elections. No fewer than 48 (79\%) of the 61 successful petitions over the 40-year period studied concerned errors on the part of the returning officer or other election officials. With the exception of Winchester in 1997, all of these petitions related to local elections. The second key tendency identified from the descriptive statistics presented above was the rise in the number of petitions making reference to voting offenses during the latter half of the period we have studied. Petitions centered on voting offenses not only became more common, having been exceptionally rare before the 1990s, they also found an increased likelihood of success. Five petitions submitted after 2004 voided local election results on the grounds of corrupt or illegal practices with respect to voting. A common denominator in these petitions has been the role of postal votes.

Space precludes discussion of all 48 successful petitions from 1977 to 2017 that arose from administrative errors. With respect to counting and computational errors, which accounted for 28 of these successful challenges, three recent examples exemplify how election petitions have been used as the only available means to correct relatively straightforward errors. In 2006, the election of British National Party (BNP) candidate Sharon Ebanks as a representative for the Kingstanding ward of Birmingham City Council arose from a double-counting error, whereby 981 extra votes were allocated to her by mistake. In 2011, two candidates with the same surname, Bob and Hazel Charlesworth (husband and wife, both standing for the Liberal Democrats), contesting the Eastwood North and Greasley (Beauvale) ward of Broxtowe Borough Council were mixed up by the returning officer, with the wrong winner being declared. At the 2012 Denbighshire 
County Council elections, 240 votes for P. Penlington, the Labour candidate, were mistakenly credited to A. Pennington, the Conservative candidate, resulting in the latter being mistakenly declared to have been elected, at the expense of the former. In at least five other petition cases, the discrepancy between the original and the corrected result was substantial and the returning officer (and generally all candidates) accepted that a mistake had been made. For example, in 2003, it became apparent that a mistake had been made in adding up the votes received by candidates in the election to Seneley Green parish of St Helens Borough Council after a counter failed to zero his calculator before starting to calculate the votes cast for a candidate. Nonetheless, these mistakes could only be rectified via a petition.

A further 16 successful petitions arose from cases involving disputes about the inclusion or exclusion of particular ballot papers from the count in contests where the result was exceptionally close. The great majority of such cases centered on the validity, or otherwise, of ballots which lacked the official mark that is required to be added by polling station staff when issuing the ballot. The Winchester election petition following the 1997 general election, discussed above, is by far the best known of these cases and exemplifies the issues typically raised in such cases. However, other forms of controversy about the inclusion or exclusion of specific ballots also led to successful petitions. In 2001, the election to the South Ribble North West division of Lancashire County Council was voided owing to the inclusion in the count of ballot papers which had listed the candidates' names incorrectly and had been issued for five hours on polling day before being withdrawn. In another case, where an allpostal ballot was piloted in the 2003 local elections in the Broughton and Appleby ward of North Lincolnshire District Council, a successful petition hinged on the inclusion of a single postal vote for which no associated declaration of identity had been returned.

The 2003 Broughton and Appleby petition is one of eight lodged since 2000 where alleged administrative problems have been associated with postal votes. Such cases were most common in the period immediately after the introduction of postal voting on demand in 2001. However, while there have been numerous cases of significant administrative errors involving postal votes, only one election pe- tition has successfully used such grounds to overturn an election result. This case concerned the Derringham ward of Hull City Council in 2004, where the petitioner, independent candidate John Considine, had lost by just seven votes following six recounts. Considine was successful on the grounds that a number of voters in Derringham had instead received postal ballots relating to the election in the Marfleet ward.

\section{Election petitions and the re-emergence of electoral fraud}

Postal voting was also the key driver of a growth in petitions alleging voting offenses after 2001. Ten petitions from 2004 to 2016 made allegations of voting offenses that included malpractice associated with postal ballots. Five of these petitions, all heard by Richard Mawrey QC, were to result in elections being voided. These hearings, and Mawrey's subsequent written judgments, provided detailed insight into the vulnerabilities of British elections to registration and postal vote fraud, highlighting the need for additional safeguards. The most widely known of these cases was the judgment on the two petitions challenging local election results, respectively, in the Aston and Bordesley Green wards of Birmingham City Council in 2004. Both petitions were issued by representatives of rival parties challenging the return of Labour candidates and were heard simultaneously between 21 February and 22 March 2005. In his judgment, which voided both results, Mawrey (2005) found that "the evidence of fraud was overwhelming," with at least 1,500 fraudulent postal ballots submitted in the two wards. Among other irregularities, large numbers of blank postal votes relating to the Aston ward were found to have been taken to a warehouse, where they were completed by Labour Party representatives. A total of six Labour Party representatives were found to have been engaged in corrupt and illegal practices in the two wards, although one of the six respondents, Muhammed Afzal, was subsequently cleared of any wrongdoing by the Court of Appeal in May 2005.

The scale of fraud identified by the Bordesley Green and Aston was without precedent in recent British political history. The commissioner's written judgment identified numerous, generic weaknesses in postal voting, including "seriously defective" procedures for registering voters for postal ballots, 
the ineffectual nature of declarations of identity as a safeguard against fraud, and the lack of any ban on third parties handling completed postal ballots. Mawrey was damning about government insistence that robust safeguards were in place. "The fact is," he countered, "that there are no systems to deal realistically with fraud and there never have been. Until there are, fraud will continue unabated."

The Birmingham Election Court was the principal catalyst for the changes to postal voting procedures introduced in the Electoral Administration Act of 2006. However, several of the fundamental concerns expressed in Mawrey's judgment remained unaddressed by the 2006 Act, and further instances of voting offenses came to light via petitions lodged in 2008 (Slough), 2012 (Woking) and 2014 (Tower Hamlets). In each case, postal voting vulnerabilities were highlighted, alongside other issues, notably the registration of "ghost electors" in Slough and Woking, and a litany of offenses in Tower Hamlets. As with the Birmingham petitions, these cases were instrumental in prompting governments to take action to protect the security of the ballot.

In Slough, the election of Raka Khan, the Conservative candidate, in Central ward was challenged by the unsuccessful Labour candidates on the grounds of corrupt and illegal practices. Mawrey (2008) ruled that Khan had engaged in a "massive campaign" of fraudulently adding names to the electoral register in order to procure postal ballots and voided the election. Criminal convictions were brought subsequently against six individuals, including Khan who was sentenced to three and a half years in prison for perjury, conspiracy to defraud, and conspiracy to pervert the course of judgment. In his written judgment Mawrey asserted: "Roll stuffing is childishly simple to commit and very difficult to detect. To ignore the probability that it is widespread, particularly in local elections, is a policy that even an ostrich would despise" (2008). The following year, the Labour government signaled its intention to phase in reforms of voter registration, via the Political Parties and Elections Act 2009 , by introducing a requirement on electors to register individually, rather than as a household, and to supply their national insurance number when doing so. The introduction of "individual elector registration" was subsequently accelerated by the Conservative-Liberal Democrat coalition via the Electoral Registration and Administration Act 2013.
Meanwhile, another election petition alleging fraudulent registrations and postal voting abuse had been heard by Mawrey. In Woking, the election of Liberal Democrat Mohammed Bashir was challenged by the Labour candidate, Mohammed Ali. Again, Mawrey (2013) voided the election, pointing to large-scale registration of ghost voters and harvesting of postal votes. Subsequent criminal convictions for conspiracy to defraud were brought against five of Bashir's relatives, resulting in prison sentences of between six and fifteen months.

The fifth successful petition whose primary grounds were voting offenses related to the election of Lutfur Rahman as mayor of the London Borough of Tower Hamlets in 2014. Rahman's election was challenged in a petition brought by four local electors and was overturned by an election court in April 2015. In voiding the election in this instance, Mawrey (2015) pointed to evidence of an array of corrupt and illegal practices, including postal vote offenses as well as bribery, treating, false statements about a rival candidate, and undue spiritual influence. Rahman and his aide, Alibor Choudhury, were found guilty of corrupt and illegal practices, removed from office, and barred from office and from voting for five years. The Tower Hamlets petition received extensive media coverage and was the key impetus behind the Pickles report on electoral fraud, published in August 2016. As Pickles noted in the foreword to his report, "The events and judgment in the Tower Hamlets case loom large in this review with significant evidence being related to that case" (2016). Approximately half of the 50 recommendations Pickles makes in the report are supported in part by the issues brought to light by the Tower Hamlets petition.

\section{CONCLUSION}

Until recently, discussion of the integrity of UK elections operated in a near-vacuum of information. Nowhere was this tendency more evident than with respect to election petitions. Aside from the lack of statistics about their frequency, grounds, and outcomes, few election petitions are reported in official law reports or elsewhere. Beyond a very small group of specialist election lawyers, knowledge of the issues highlighted by election petitions, and of the limitations of the petitioning process, is therefore exceptionally scant. In presenting new data about 
petitions from 1900 to 2016 , we aim to address these shortcomings and inform current debates about the reform of the petition mechanism. In addition to improving the accuracy of information about petitions relating to parliamentary elections since 1945 , our data provides the only comprehensive set of statistics for local election petitions in England and Wales since 1900. We have been able to assess whether threats to electoral integrity have changed over time and evaluate how petitions have been used to challenge election outcomes. The cases we have examined also add clear weight to the primary criticisms of the petition process advanced in recent reviews. These include the legal and financial barriers facing petitioners, the bar on returning officers bringing petitions, the assumption that election challenges are a private concern, rather than a matter of public interest, and the absence of other mechanisms for review or complaints where the outcome of the election is not in doubt.

From our findings, it is evident that, while not widely used, at no stage did the petition mechanism become entirely redundant or irrelevant. The increase in the number of petitions since the 1970s is notable and will come as a surprise to many seasoned observers of elections. It is also clear that the uses of the petition mechanism today have become very different to those envisaged by the authors of the 1868 Parliamentary Elections Act. The great majority of successful petitions since 1977 have related to administrative mistakes made in local elections, rather than to corrupt and illegal practices by parliamentary candidates. Likewise, the recent rise in the number of petitions alleging corrupt and illegal practices in local elections has been associated with the availability of postal voting on demand, a development that the Victorians would never have foreseen or contemplated.

As we have shown, correcting errors made either in the process of counting votes or when transposing vote totals before making an official declaration of the result has become the primary effective use of the petition mechanism. Our data suggest no grounds to indicate that such problems of maladministration are widespread in British elections. Nonetheless, election petitions submitted over a 40 -year period underline that mistakes do sometimes occur and that a mechanism is needed to deal with them. However, petition cases attest to a number of serious shortcomings arising from this dependency on the petition mechanism to correct often straightforward counting errors. As private legal actions, petition hearings generally result in legal costs of tens of thousands of pounds being incurred, even if the outcome is essentially little more than a supervised recount being ordered. Candidates or electors must instigate these costly, and complex, proceedings, even where the returning officer accepts he or she has made a mistake. As both Pickles (2016) and the Law Commission (2016) have proposed, there are powerful arguments in favor of a returning officer being able to bring a petition in these, and other, circumstances. There is also a clear need to streamline the process for cases involving administrative errors. Even where the nature of the mistake is clear, and widely accepted by the participants in the election, it can take two to three months until a universally acknowledged error at an election count can be officially recognized and the winning candidate is able to take his or her seat.

The relevance of the petition mechanism is also starkly underlined by the five successful petitions lodged since 2004 with respect to voting offenses. In the absence of the petition hearings, it is difficult to see how the vulnerabilities of postal voting would have been exposed as clearly, comprehensively, or authoritatively as they were. The impact of these petitions in bringing about actual and proposed legislative reform since 2006 has been clearly evident, and it is incongruous that petitions must be launched as private legal actions. There is an obvious public interest served by these petition cases, which have brought to light generic weaknesses in how electoral integrity is protected as much as they have highlighted breaches of the law by individuals. As both Pickles (2016) and the Law Commission (2016) have proposed, there is therefore a powerful case for bringing petitions into the ordinary courts and to clarify that the courts are able to make protective orders for costs.

Finally, given the clear access to justice issues, and the high bar which must be cleared for an election result to be overturned, many instances of maladministration and malpractice never reach the stage of triggering an election petition. Even with extensive reform, election petitions would almost certainly remain ill-suited to the task of addressing wider failings in elections and decision making about how to prevent them recurring. Future research could usefully consider the extent to which data relating to petitions can be compared against other available indicators of administrative 
failings or electoral offenses and what mechanisms, if any, have been used, and by whom, in cases where no petition arose. Based on our findings, we would also endorse proposals (cf., Pickles 2016; Law Commission 2016) for a means of complaining about the administration of an election, for instance to an ombudsman, without seeking to challenge the result.

\section{REFERENCES}

Absalom v. Gillett, [1995] 1 WLR 128.

Ahmed v. Kennedy, [2002] EWCA Civ 1793.

Butler, D. (1999). "Elections: Legislation and Litigation," in Butler, D., Bogdanor V., and Summers, R. (eds.), The Law, Politics and the Constitution, Oxford: Oxford University Press.

Butler, D. and Rose, R. (1959). The British General Election of 1959, Basingstoke: Macmillan.

Carr Committee (1948). Final Report of the Committee on Electoral Law Reform, Cmd 7286, London: HMSO.

Craig, F.W.S. (1976). British Electoral Facts, 1885-1975, Basingstoke: Macmillan.

Electoral Commission (2012). Challenging Elections in the $U K$, London: Electoral Commission.

Grist, R. (2015). "Challenging Elections in the Courts," Public Law, (July): 375.

House of Commons Debate 30 July 1982, vol. 28, col. 731W.

House of Commons Debate 22 November 1995, vol. 267, col. $223 \mathrm{~W}$.

House of Commons Debate 24 May 2005, vol. 434, col. 93W. House of Commons Debate 22 March 2007, vol. 458, col.1104W. House of Commons Debate 28 March 2007, vol. 458, col.1562W. House of Commons Debate 25 February 2013, vol. 559, col.184W. Hussein v. Khan, [2006] EWHC 262.

Kwa, E., Gelu, A., and Golman, W. (eds) (2003). Judicial Scrutiny of the Electoral Process in a Developing Democratic State, Port Moresby: UPNG/UBS Publishers.

Lardy, H. (2007). "Challenging Elections," Scottish Legal Action Group Journal, 357: 139, 143.

Law Commission (2016). Electoral Law: Interim Report, Law Commission, Scottish Law Commission and Northern Ireland Law Commission, joint report.

Mawrey, R. (2005). Akhtar v. Jahan; Iqbal v. Islam, [2005] All ER (D) 15.

Mawrey, R. (2008). Simmons v. Khan, [2008] EWHC B4 (QB). Mawrey, R. (2013). Ali v. Bashir, [2013] EWHC 2572 (QB).
Mawrey, R. (2015). Erlam \& Ors v. Rahman \& Anor, [2015] EWHC 1215 (QB).

Miller v. Bull, [2009] EWHC 2640.

Morris, C. (2012). Parliamentary Elections, Representation and the Law, London: Bloomsbury.

O'Leary, C. (1962). The Elimination of Corrupt Practices in British Elections, 1868-1911, Oxford: Clarendon Press.

O'Leary, C. (1965). "The Wedgwood Benn Case and the Doctrine of Wilful Perversity," Political Studies, 13(1): 65-78.

Orr, G. (2017). "Integrity on the Line: Judicial Power over Elections in Papua New Guinea," LAWAsia Journal, 65-81.

Orr, G. (2015). Ritual and Rhythm in Electoral Systems: A Comparative Legal Approach, London: Routledge.

Orr, G and Williams, G. (2001). "Electoral Challenges: Judicial Review of Parliamentary Elections in Australia," Sydney Law Review, 23: 53-94.

Pickles, E. (2016). Securing the Ballot: Review into Electoral Fraud, London: Cabinet Office.

Prideaux v. Morrice, [1702] 87 ER 1065.

$R$ (on the application of Woolas) v. Parliamentary Election Court, [2010] EWHC 3169 (Admin.).

Rallings, C. and Thrasher, M. (2009). British Electoral Facts, London: Total Politics/Biteback Publishing Limited.

Representation of the People Act (1983). <http://www.legislation .gov.uk/ukpga/1983/2>.

Stewart, J. (2006). "Banana Republic? The Investigation into Electoral Fraud by the Birmingham Election Court," Parliamentary Affairs, 59(4): 654-667.

Watt, B. (2006). UK Election Law: A Critical Examination, London: Routledge.

Wilks-Heeg, S. (2008). Purity of Elections in the UK: Causes for Concern, York: Joseph Rowntree Reform Trust.

Address correspondence to:

Caroline Morris

School of Law

Queen Mary University of London

Mile End Road

London E1 4NS

United Kingdom

E-mail: c.morris@qmul.ac.uk

Received for publication July 6, 2018; received in revised form September 14, 2018; accepted September 18, 2018; published online December 26, 2018. 